\title{
Cancer of the testis, socioeconomic status, and occupation
}

\author{
A J Swerdlow, A J Douglas, S R A Huttly, P G Smith
}

\begin{abstract}
The risk of testicular cancer in relation to lifetime histories of socioeconomic status, occupation, and occupational exposures was examined in a case-control study in England. Interviews were conducted with 259 cases, 238 control patients treated at radiotherapy and oncology centres, and 251 controls who were hospital inpatients in other departments. Risk of testicular cancer was raised in men of high socioeconomic status measured both by occupation and in other ways, and was similar in relation to status measured at birth and at various later stages of life. The occupations with highest risk of the tumour were paper and printing workers, professionals, and administrators. Exposures to various specific occupational agents that have been suggested in publications as potential risk factors were examined, but none showed an association with risk. The relative risk for occupational exposure to ionising radiation was 1.62 (95\% confidence interval $0 \cdot 83-3 \cdot 17$ ).
\end{abstract}

Testicular cancer is increasing in incidence in many developed countries but its causes remain largely unknown. One clue to the type of factors likely to be responsible is the finding in almost all studies of an association with high socioeconomic status. ${ }^{1-5}$ Corresponding to this, risk has been found to be raised in men in professional and managerial occupations. ${ }^{1-6}$ Recently there have also been reports, as yet unconfirmed, of much raised risk in narrower occupational groups, which might implicate more specific occupational aetiological agents. Such groups include podiatrists, ${ }^{7}$ workers in oil and natural gas extraction, ${ }^{8}$ workers with brominated chemicals, ${ }^{9}$ aircraft repairmen, ${ }^{10}$ tannery workers, ${ }^{11}$ naval mechanics, ${ }^{12}$ and painters. ${ }^{13}$ Farmers have been found to be at raised risk in several but not all studies. ${ }^{15}$

Department of Epidemiology and Population Sciences, London School of Hygiene and Tropical Medicine, Keppel Street, London WC1E 7HT

A J Swerdlow, A J Douglas, S R A Huttly, P G Smith
These reports have been based mainly on measures of social class and occupation at the time of presentation with testicular cancer, whereas the aetiological exposures for the tumour presumably occurred much earlier. If the associations with class or occupation are real, they should be stronger for measures at the relevant time of life, which might be many years before presentation, perhaps even prenatally.

Our present analysis, from an interview casecontrol study in England, examined the risk of testicular cancer in relation to lifetime histories of socioeconomic status, occupation, and certain occupational exposures.

\section{Materials and methods}

The investigation was a stratum matched casecontrol study. The cases were 259 patients with primary testicular cancer incident January 1977February 1981, resident in the catchment areas of the radiotherapy and oncology centres in Oxford, Northampton, Reading, Cheltenham, Birmingham, and Coventry, and aged at least 10 years at presentation. One hundred and thirty eight of the cases had seminoma, 104 had teratoma, and 17 had other histologies and cancers of mixed histology. Thirty seven $(14 \%)$ of the subjects were aged $10-24$ at presentation, $101(39 \%)$ were aged $25-34,74(29 \%)$ were aged $35-44$, and $47(18 \%)$ were older than this, The cases were similar in age and histology distribution to the 469 testicular cancers incident in the catchment population during the study period, except that the cases included a lower proportion of men over 54 years of age ( $7 \%$ of the cases, but $12 \%$ of the testicular cancers in the catchment population).

Two sets of controls incident during the same period were interviewed similarly to the cases. The first control group were 238 patients treated at the same radiotherapy and oncology centres as the cases. The most frequent diagnoses in these controls were Hodgkin's disease (83 patients), non-Hodgkin's lymphoma (31), brain tumour (23), and bladder cancer (18). The other set of controls were 251 general surgical, orthopaedic, ear, nose, and throat, and dental inpatients at hospitals in the same towns as the centres, with a wide range of non-malignant conditions incident during the same period as the cases. The most frequent diagnoses of these controls were 
deflected nasal septum (19 patients), disorders of tooth eruption (18 patients), haemorrhoids (16 patients), and acute tonsillitis (15 patients). Greater detail about the cases, controls, and non-respondents are given in Swerdlow et al. ${ }^{14}$

During April 1979 to March 1981, the subjects were questioned using a structured interview schedule about several possible risk factors for cancer of the testis including educational history, all occupations held for six months or more, various specific occupational exposures, mainly connected with farming, and the occupation and hence social class of the subject's father both at the time of the subject's birth and when the subject was a child. Occupation and social class were coded according the Office of Population Censuses and Surveys classification. ${ }^{15}$

Analyses were by stratum matched logistic regression $^{16}$ using the computer program EGRET. ${ }^{17}$ Relative risks were estimated in relation to the variables examined in the study after stratification for age (two year age groups between 20 and 49 years of age, plus the groups $<20,50-54,55-59$, and $\geqslant 60$ ) and two regions of residence (West Midlands and the Oxford region including Cheltenham). Risks were examined both for testicular cancer overall, and for teratoma and seminoma separately. The latter analyses did not show any clear differences in risk by histology for the variables considered here, and therefore have not been presented. Analyses were also conducted separately for each control group, and then, when these results were similar, for the two control groups combined.

\section{Results}

Several different measures of socioeconomic status, at different stages of life, were analysed. For each the risk was found to be similar when compared with each of the two control groups. Table 1 shows the occupation based measures of social class at birth, childhood (father's occupation), and at the case's index presentation (own occupation). At each age risk was greatest in men of high social class. The gradients of risk were not entirely even. Linear trend tests were significant at each stage of life, with somewhat higher significance levels at more recent ages.

In accord with these findings, risk of testicular cancer was greatest for men who had attended public schools (fee-paying, often boarding, schools) and grammar schools (also selective), and lower for those who had been educated at less selective schools (table 2). The proportion of subjects educated at boarding schools was similar for cases and controls.

Risk of testicular cancer was increased for men who had left full time education after the minimum school leaving age (table 2) but within this group, risk was greater for men ending education at age 17-19 than for those who continued beyond this (the overall gradient of risk with age of leaving education was just significant). Correspondingly, risk for university graduates (table 2) (who would have ended education after age 19) was only slightly above that for nongraduates.

Risk in relation to occupation was examined for occupation at age 20 , at age 30 , for the longest held occupation, for ever held occupation, and for that most recently held. There was no clear difference between the results from these analyses. Table 3 shows risks of testicular cancer by ever held occupation. For each occupation the risk among men who had ever been in the occupation was compared with that of those who had never held the occupation. The only statistically significant finding was of a reduced risk in men who had ever been service or recreation workers (odds ratio (OR) $0.51,95 \%$ confidence interval ( $95 \% \mathrm{CI}) 0 \cdot 31-0 \cdot 85)$; risks for this group were similar when compared with each of the two control groups separately. The greatest risks were for paper and printing workers (OR $2 \cdot 05,95 \%$ CI $0 \cdot 84$ $5 \cdot 02$ ), administrators and managers (OR $1.33,95 \%$

Table 1 Risks of testicular cancer by social class at birth, in childhood, and at presentation

\begin{tabular}{|c|c|c|c|}
\hline & $\begin{array}{l}\text { Social class of father } \\
\text { at birth of subject } \\
(O R(95 \% \text { CI }) \text { ) }\end{array}$ & $\begin{array}{l}\text { Social class of father } \\
\text { when subject was a child } \\
(O R(95 \% \text { CI) ) }\end{array}$ & $\begin{array}{l}\text { Social class of subject } \\
\text { at presentation } \\
(O R(95 \% C I))\end{array}$ \\
\hline $\begin{array}{l}\text { Social class: } \\
\text { I } \\
\text { II } \\
\text { IIIN } \\
\text { IIIM } \\
\text { IV } \\
\text { V } \\
\text { Armed forces } \\
\chi_{1}^{2} \text { Trend I-V (significance) } \\
\text { No of cases included in analysis } \\
\text { No of controls included in analysis }\end{array}$ & $\begin{array}{ll}1.48 & (0.69-3 \cdot 16) \\
1.25 & (0.71-2 \cdot 19) \\
1.51 & (0.85-2 \cdot 67) \\
1.00 & \\
0.79 & (0.48-1 \cdot 30) \\
0.85 & (0.42-1 \cdot 72) \\
1.02 & (0.58-1.79) \\
3.10 & (\mathrm{p}=0.08) \\
238 & \\
451 & \end{array}$ & $\begin{array}{ll}1.48 & (0.68-3 \cdot 23) \\
1.66 & (1.03-2 \cdot 67) \\
1.45 & (0.84-2 \cdot 49) \\
1.00 & \\
0.81 & (0.51-1 \cdot 29) \\
1.09 & (0.56-2 \cdot 14) \\
1.22 & (0.50-2.98) \\
5.49 & (\mathrm{p}=0.02) \\
254 & \\
471 & \end{array}$ & $\begin{array}{ll}1.99 & (1 \cdot 14-3.47) \\
1.61 & (1 \cdot 04-2 \cdot 50) \\
1.42 & (0.81-2 \cdot 52) \\
1.00 & \\
1.11 & (0.67-1.85) \\
1.10 & (0.47-2 \cdot 57) \\
-\star \star & \\
6.71 & (p=0.01) \\
240 & \\
470 & \end{array}$ \\
\hline
\end{tabular}

^Excluding 19 cases and 34 controls at birth, four cases and 13 controls in childhood, and six cases and seven controls at presentation, for whom social class was not known or inapplicable (for example, because the father had died), and two cases, four controls at birth, one case, five controls in childhood, and 13 cases, 11 controls at presentation known not to be in paid employment (retired, students, etc). $\star \star$ Not calculated: no cases, one control in this occupation. 
Table 2 Risks of testicular cancer by educational background

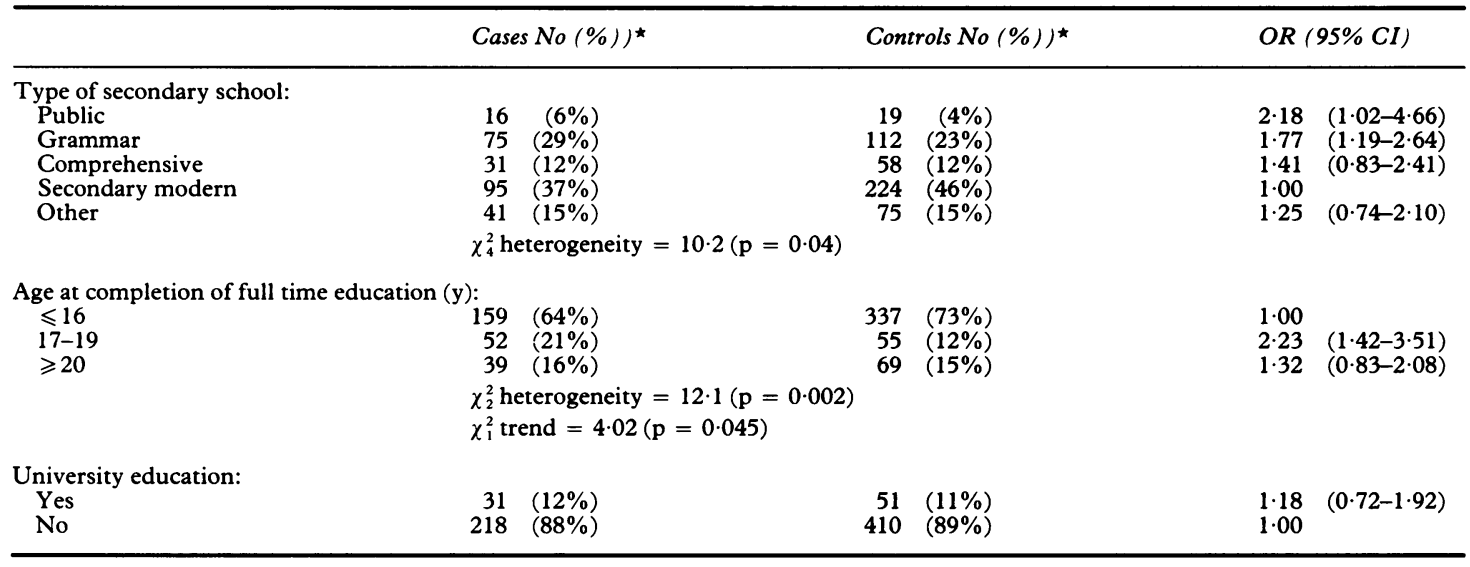

^From 258 cases, 488 controls with variable known for type of secondary school; 250 cases, 461 controls for age at end of education; and 249 cases, 461 controls for university education. Men under age 20 at presentation were excluded from the two latter analyses.

Table 3 Risk of testicular cancer in relation to ever-work in selected occupation orders

\begin{tabular}{|c|c|c|c|c|c|c|c|}
\hline \multicolumn{2}{|c|}{ Occupation code and description } & \multicolumn{2}{|c|}{$\begin{array}{l}\text { No }(\%)^{\star} \text { of cases } \\
\text { with the occupation }\end{array}$} & \multicolumn{2}{|c|}{$\begin{array}{l}\text { No }(\%)^{\star} \text { of controls } \\
\text { with the occupation }\end{array}$} & \multicolumn{2}{|c|}{$O R(95 \% C I)$} \\
\hline $\begin{array}{l}\text { I } \\
\text { VI } \\
\text { VIII } \\
\text { IX } \\
\text { XIII } \\
\text { XVI } \\
\text { XIX } \\
\text { XXI } \\
\text { XXII } \\
\text { XXIII } \\
\text { XXIV } \\
\text { XXV } \\
\text { XXVI }\end{array}$ & $\begin{array}{l}\text { Farmers, foresters, fishermen } \\
\text { Electrical workers } \\
\text { Engineering workers } \\
\text { Woodworkers } \\
\text { Leatherworkers } \\
\text { Paper and printing workers } \\
\text { Painters and decorators } \\
\text { Transport and communication workers } \\
\text { Clerical workers } \\
\text { Sales workers } \\
\text { Service and recreation workers } \\
\text { Administrators } \\
\text { Professionals } \\
\text { Armed forces }\end{array}$ & $\begin{array}{r}27 \\
16 \\
81 \\
11 \\
5 \\
10 \\
8 \\
32 \\
41 \\
47 \\
23 \\
22 \\
77 \\
56\end{array}$ & $\begin{array}{r}(10) \\
(6) \\
(31) \\
(4) \\
(2) \\
(4) \\
(3) \\
(12) \\
(16) \\
(18) \\
(9) \\
(8) \\
(30) \\
(22)\end{array}$ & $\begin{array}{r}46 \\
44 \\
176 \\
29 \\
9 \\
12 \\
20 \\
55 \\
66 \\
93 \\
74 \\
30 \\
122 \\
135\end{array}$ & $\begin{array}{r}(9) \\
(9) \\
(36) \\
(6) \\
(2) \\
(2) \\
(4) \\
(11) \\
(13) \\
(19) \\
(15) \\
(6) \\
(25) \\
(28)\end{array}$ & $\begin{array}{l}1.09 \\
0.74 \\
0.73 \\
0.74 \\
1.05 \\
2.05 \\
0.83 \\
1.03 \\
1.25 \\
0.91 \\
0.51 \\
1.33 \\
1.29 \\
0.84\end{array}$ & $\begin{array}{l}(0.65-1.83) \\
(0.40-1.37) \\
(0.52-1.03) \\
(0.35-1.53) \\
(0.33-3.42) \\
(0.84-5.02) \\
(0.35-1.97) \\
(0.64-1.68) \\
(0.80-1.96) \\
(0.60-1.36) \\
(0.31-0.85) \\
(0.74-2.42) \\
(0.90-1.84) \\
(0.53-1.33)\end{array}$ \\
\hline
\end{tabular}

^All from 259 cases, 489 controls.

CI 0.74-2.42), professionals and related workers (OR $1 \cdot 29,95 \%$ CI $0 \cdot 90-1 \cdot 84$ ), and clerical workers (OR $1 \cdot 25,95 \%$ CI $0 \cdot 80-1 \cdot 96$ ). In each of these occupations risk was appreciably raised when compared with each control group separately.

Risks of testicular cancer were estimated for men who had done night work, and for various farming exposures. None showed any evidence of association with the tumour when analysed as dichotomous variables (table 4) or when analysed in relation to duration of exposure.

Risk was raised in relation to reported occupational exposure to ionising radiation, although this was not statistically significant (table 4). From their replies, it was not possible to delineate the exact types of radiation to which several of the subjects had been exposed, and we therefore divided the exposures according to the type of occupation in which they occurred. Military exposures showed a raised risk (OR 2.93, 95\% CI 0.78-10.94), but no raised risk occurred for civil nuclear and research exposures
Table 4 Risk of testicular cancer in relation to ever exposure to certain occupational factors

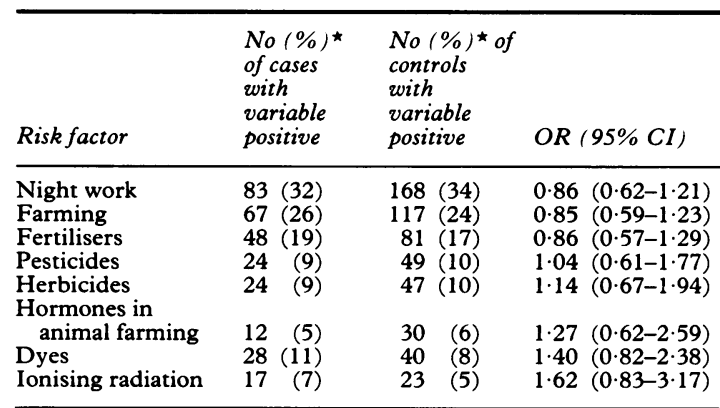

*All from 259 cases, 489 controls, except 488 controls for night work and for hormones in animal farming.

(OR $0 \cdot 87,95 \%$ CI $0 \cdot 26-2 \cdot 87$ ), and no clear excess (based on small numbers) for medical and other exposures. The military exposures included two 
cases and no controls exposed to testing of nuclear weapons, and two cases (one of whom was also exposed to weapons testing) and one control working in military research establishments. We also asked subjects about past lower body diagnostic radiography and therapeutic radiation; these were similar in cases and controls.

A non-significant relative risk of 1.4 existed for dye exposed workers (table 4). The exact types of work and exposure in printing, dye, and chemical work reported by the cases and controls were examined, but gave no indication of possible risk factors. In relation to previously suggested risk factors, two $(0.8 \%)$ cases and two $(0.4 \%)$ controls reported exposure to dyes in leather work; no subjects had worked in the oil and natural gas industry or in military aircraft maintenance and repair; and three $(1.2 \%)$ cases and three $(0.6 \%)$ controls reported wood machinery, sawing, or milling occupations.

\section{Discussion}

The study confirmed the increased risk of testicular cancer in men of high social class. Previous results for this variable have been based on current or most recent social class or on highest educational level achieved, but the present study showed raised risk also when ascertained at earlier periods of life and by various educational measures. No clear indication was found, however, of the period in life at which factors related to social class might act. It has, for instance, been suggested that testicular cancer might result from a childhood infection that has more serious consequences when contracted at an older age than usual, as occurs in poliomyelitis, and that this might account for the social class gradient. ${ }^{18}$ The present data, however, did not indicate a stronger social class association in childhood than at other ages. Others have suggested a prenatal aetiology of testicular cancer, ${ }^{19}$ but at birth the social class gradient (of fathers) was not greater than at other times. The similar results in the study using the two different control groups, suggest that any biases in social class or catchment population of specific diseases among the controls were not of substantial effect.

The raised risk of testicular cancer in professionals and administrators accords with previous work ${ }^{1-6}$ and could reflect their high social class behaviour or environment. As yet no evidence exists to support an occupational origin for this risk-for instance from sedentary work.

The raised risk for testicular cancer in printing workers corresponds with the raised risk found in a case-control study of seminoma, ${ }^{20}$ and in routine data from England and Wales ${ }^{1}$ and, based on small numbers, from the United States. ${ }^{2122}$ Examination of the specific jobs held by subjects who had worked in this occupation order gave no indication of any specific risk factor.

Work in farming has been associated with raised risk in some but not all previous studies. ${ }^{15}$ Questions on various different farming exposures in our present study, however, gave no indication of risk from any specific aspect of farming. In particular, potential exists in animal farming for exposure to sex steroid hormones used to promote growth of livestock, ${ }^{23}$ but no raised risk occurred in relation to this exposure in the present data. Wiklund and colleagues ${ }^{24}$ found a significant raised risk of testicular cancer in Swedish pesticide applicators (mainly farming and forestry workers), but we found no raised risk for pesticide use. Others have suggested possible risk from fertilisers ${ }^{25}$ and herbicides ${ }^{26}$ but again these did not give raised risk in our exposure histories.

Milham $^{27}$ found a significantly raised risk of testicular cancer in Washington State sawmill and similar workers; among our cases we found a nonsignificant excess of ever working in such occupations.

Some animal studies have shown an association between exposure to radiation and testicular cancer. ${ }^{28}$ Little information has accrued in humans, however, and the evidence to date has not identified any clear excess. ${ }^{28}$ Mortality from testicular cancer was raised by $50 \%$ (but not significantly) in a large cohort of United Kingdom atomic energy workers. ${ }^{29} \mathrm{We}$ found roughly $50 \%$ raised risk for ionising radiation exposure overall, but no raised risk for civil nuclear and research exposures. The excess for military exposures must be interpreted with caution: there seems no prior reason why military exposures overall should differ in carcinogenicity from civilian exposures (except if they might be larger), and the actual exposures of cases were varied. Larger data sets are needed to investigate this further.

Recently clusters of testicular cancers have been reported in tannery workers, ${ }^{11}$ aircraft repairmen, ${ }^{10}$ navy mechanics maintaining internal combustion engines, ${ }^{12}$ and painters, ${ }^{13}$ for whom suggested common exposures have been dimethylformamide, and heavy metal pigments, particularly chromate based dyes. ${ }^{30}$ We had few cases in the above occupations, but note that the raised risk in printers in the present study and previous data could relate to occupational exposures to chromate and other heavy metal pigments. Although one can link several high risk occupations in this way, many other occupational groups for whom raised risk is not apparent are exposed to the same agents (for example, ${ }^{31}$ ).

Considerable prominence has been given in published reports to certain occupational clusters of men with testicular cancer, but both the present data and review of publications generally, suggest that as yet no clear, consistent evidence exists to show that any 
occupational exposure is a cause of the disease.

We thank the Cancer Research Campaign for funding the study; Professor Sir Richard Doll and Professor M P Vessey for advice; Professor Vessey and Dr E R Rue for support; the clinicians, their staff and others who cooperated and helped with the study and provided notification of cases; Mrs M A Ainley and Miss $M M$ Stone for sensitive and skilful interviewing of the patients; and Mrs F Garven, Miss $\mathrm{J}$ Clark, and Mr A Radalowicz for computer programming.

1 Swerdlow AJ, Skeet RG. Occupational associations of testicular cancer in south east England. Br J Ind Med 1988;45:225-30.

2 Mustacchi P, Millmore D. Racial and occupational variations in cancer of the testis: San Francisco, 1956-65. J Natl Cancer Inst 1976;56:717-20.

3 Registrar General Office of Population Censuses and Surveys. The Registrar General's decennial supplement for England and Wales, 1961, 1970-72. Occupational mortality. London: HMSO, 1971, 1978.

4 Ross RK, McCurtis JW, Henderson BE, Menck HR, Mack TM, Martin SP. Descriptive epidemiology of testicular and prostatic cancer in Los Angeles. Br J Cancer 1979;39:284-92.

5 Pearce N, Sheppard RA, Howard JK, Fraser J, Lilley BM. Time trends and occupational differences in cancer of the testis in New Zealand. Cancer 1987;59:1677-82.

6 Graham S, Gibson RW. Social epidemiology of cancer of the testis. Cancer 1972;29:1242-9.

7 Rose LI, Weiss W, Gibley CW Jr, Borowski G, Levy RA. Carcinoma of the testis in podiatrists. Ann Intern Med 1983; 99:636-7.

8 Mills PK, Newell GR, Johnson DE. Testicular cancer associated with employment in agriculture and oil and natural gas extraction. Lancet 1984;i:207-10.

9 Wong O, Brocker W, Davis HV, Nagle GS. Mortality of workers potentially exposed to organic and inorganic brominated chemicals, DBCP, TRIS, PBB, and DDT. Br J Ind Med 1984; 41:15-24.

10 Ducatman AM, Conwill DE, Crawl J. Germ cell tumors of the testicle among aircraft repairmen. J Urol 1986;136:834-6.

11 Levin SM, Baker DB, Landrigan PJ, et al. Testicular cancer in leather tanners exposer, to dimethylformamide. Lancet 1987; ii: 1153 .
12 Garland FC, Gorham ED, Garland CF, Ducatman AM. Testicular cancer in US Navy personnel. Am J Epidemiol 1988;127: 411-4.

13 Gubéran E, Usel M, Raymond L, Tissot R, Sweetman PM. Disability, mortality, and incidence of cancer among Geneva painters and electricians: a historical prospective study. $\mathrm{Br} J$ Ind Med 1989;46:16-23.

14 Swerdlow AJ, Huttly SRA, Smith PG. Testicular cancer and antecedent diseases. Br J Cancer 1987;55:97-103.

15 Office of Population Censuses and Surveys. Classification of Occupations, 1970. London: HMSO, 1970.

16 Breslow NE, Day NE. Statistical methods in cancer research. Vol 1. The analysis of case-control studies. Lyon: International Agency for Research on Cancer, 1980. (Sci publ No 32.)

17 Statistics and Epidemiology Research Corporation. EGRET. Seattle: Statistics and Epidemiology Research Corporation, 1989.

18 Newell GR, Mills PK, Johnson DE. Epidemiologic comparison of cancer of the testis and Hodgkin's disease among young males. Cancer 1984;54:1117-23.

19 Henderson BE, Ross RK, Pike MC, Depue RH. Epidemiology of testis cancer. In: Skinner DG, ed. Urological Cancer. New York: Grune and Stratton, 1983:237-50.

20 Coldman AJ, Elwood JM, Gallagher RP. Sports activities and risk of testicular cancer. Br J Cancer 1982;46:749-56.

21 Houten L, Bross IDJ, Viadana E. A retrospective survey of cancer in relation to occupation. Cincinnati: National Institute for Occupational Safety and Health, 1977. (DHEW (NIOSH) publ No 77-178.)

22 Milham S Jr. Occupational mortality in Washington State 19501979. Cincinnati: National Institute for Occupational Safety and Health, 1983. (DHHS (NIOSH) publ No 83-116.)

23 Lamming GE. Growth promoting hormones. Journal of the Royal Society of Health 1983;103:8-11.

24 Wiklund K, Dich J, Holm L-E, Eklund G. Risk of cancer in pesticide applicators in Swedish agriculture. $\mathrm{Br} J$ Ind Med 1989;46:809-14.

25 Haughey BP, Graham S, Brasure J, Zielezny M, Sufrin G, Burnett WS. The epidemiology of testicular cancer in upstate New York. Am J Epidemiol 1989;130:25-36.

26 Hayes HM, Tarone RE, Casey HW, Huxsoll DL. Excess of seminomas observed in Vietnam service US military working dogs. J Natl Cancer Inst 1990;82:1042-6.

27 Milham S Jr. Neoplasia in the wood and pulp industry. Ann NY Acad Sci 1976;271:294-300.

28 National Research Council. Health effects of exposure to low levels of ionizing radiation. BEIR $V$. Washington, DC: National Academy Press, 1990

29 Beral V, Inskip H, Fraser P, Booth M, Coleman D, Rose G Mortality of employees of the United Kingdom Atomic Energy Authority, 1946-1979. BMJ 1985;291:440-7.

30 Ducatman AM. Dimethylformamide, metal dyes, and testicular cancer. Lancet 1989;i:911.

31 Chen JL, Kennedy GL Jr. Dimethylformamide and testicular cancer. Lancet 1988;i:55.

Accepted 4 March 1991 